\title{
Minor psychiatric disorders in nursing: prevalence and associated factors
}

\author{
Distúrbios psíquicos menores na enfermagem: prevalência e fatores associados \\ Disturbios psíquicos menores en la enfermería: la prevalencia y los factores asociados
}

Evelin Daiane Gabriel Pinhatti', Renata Perfeito Ribeiro', Marcos Hirata Soares',
Júlia Trevisan Martins', Maria Ribeiro Lacerda"
'Universidade Estadual de Londrina. Londrina, Paraná, Brazil.
"Universidade Federal do Paraná. Curitiba, Paraná, Brazil.

How to cite this article:

Pinhatti EDG, Ribeiro RP, Soares MH, Martins JT, Lacerda MR. Minor psychiatric disorders in nursing: prevalence and associated factors. Rev Bras Enferm [Internet]. 2018;71(Suppl 5):2176-83.

[Thematic Issue: Mental health] DOI: http://dx.doi.org/10.1590/0034-7167-2018-0028

Submission: 01-30-2018

Approval: 04-20-2018

\begin{abstract}
Objective: to investigate the prevalence of Minor Psychiatric Disorders and associated factors in nursing workers. Method: observational and analytical sectional study. Data were collected from 285 nursing workers. A questionnaire containing sociodemographic, occupational, psychosocial aspects of work and mental health was used. Bivariate and multivariate analysis were performed by binary logistic regression. Results: the global prevalence of suspected Minor Psychiatric Disorders among nursing workers was $32.6 \%$. Higher prevalence rates were found among female, young, married/common-law married individuals, in the nursing assistant/technician categories, with income up to four minimum wages, developing high-demand work with low social support, high effort-reward imbalance, and over-commitment. Conclusion: the variables that remained associated with the mental health outcome in the final model were: female gender, married/common-law married, high-demand work, high effort-reward imbalance, and over-commitment. Descriptors: Nursing; Occupational Health; Nursing Research; Working Environment; Mental Disorders.
\end{abstract}

\section{RESUMO}

Objetivo: investigar a prevalência de Distúrbios Psíquicos Menores e os fatores associados em trabalhadores de enfermagem. Método: estudo seccional, observacional e analítico. Os dados foram coletados junto a 285 trabalhadores de enfermagem. Utilizou-se questionário contendo variáveis sociodemográficas, ocupacionais, aspectos psicossociais do trabalho e de saúde mental. Realizada análise bivariada e multivariada por regressão logística binária. Resultados: a prevalência global para suspeição de Distúrbios Psíquicos Menores entre os trabalhadores de enfermagem foi de $32,6 \%$. Foram encontradas maiores prevalências entre indivíduos do sexo feminino, jovens, casados/com união estável, nas categorias auxiliar/técnico de enfermagem, com renda de até quatro salários mínimos, desenvolvendo o trabalho de alta exigência, com baixo apoio social, alto desequilíbrio esforço-recompensa e excesso de comprometimento. Conclusão: as variáveis que permaneceram associadas ao desfecho de saúde mental no modelo final foram: sexo feminino, situação conjugal casado/ união estável, trabalho de alta exigência, alto desequilíbrio esforço-recompensa e presença de comprometimento excessivo.

Descritores: Enfermagem; Saúde do Trabalhador; Pesquisa em Enfermagem; Ambiente de Trabalho; Transtornos Mentais.

\section{RESUMEN}

Objetivo: investigar la prevalencia de Disturbios Psíquicos Menores y los factores asociados en trabajadores de enfermería. Método: estudio seccional, observacional y analítico. Los datos fueron recogidos junto a 285 trabajadores de enfermería. Se utilizó el cuestionario conteniendo las variables sociodemográficas, ocupacionales, los aspectos psicosociales del trabajo y de salud mental. Realizado el análisis bivariado y multivariado por regresión logística binaria. Resultados: la prevalencia global para la suspicacia de Disturbios Psíquicos Menores entre los trabajadores de enfermería fue del 32,6\%. Fueron encontradas prevalencias más grandes entre los individuos del sexo femenino, los jóvenes, los casados/con unión estable, en las categorías auxiliar /técnico de enfermería, con ingreso de hasta cuatro sueldos mínimos, desarrollando el trabajo de alta exigencia, con bajo apoyo social, alto desequilibrio esfuerzo-recompensa y exceso de comprometimiento. Conclusión: las variables que 
permanecieron asociadas al desfecho de salud mental en el modelo final fueron: sexo femenino, situación conyugal casado/ unión estable, trabajo de alta exigencia, alto desequilibrio esfuerzo-recompensa y presencia de comprometimiento excesivo.

Descriptores: Enfermería; Salud del Trabajador; Investigación en Enfermería; Ambiente de Trabajo; Trastornos Mentales.

\section{CORRESPONDING AUTHOR Evelin Daiane Gabriel Pinhatti E-mail: evelin.gabriel@sercomtel.com.br}

\section{INTRODUCTION}

This study plays a central role for individuals, provides structure for daily life, contributes to financial stability, enables social interaction and personal development, indispensable factors for the achievement of well-being and adequate mental health ${ }^{(1)}$.

In the current scenario, the workforce has undergone numerous political, economic and social transformations, which have influenced the health of workers ${ }^{(2)}$. In recent years, mental health of workers has become important, especially of those professionals working in health institutions ${ }^{(3)}$.

In the nursing context, these people are exposed to biological, physical, chemical, ergonomic and psychosocial risks. They also face emotional inherent demands in the profession-living with human suffering, pain and death, direct and prolonged contact with patients-becoming a source of additional mental burden ${ }^{(4-5)}$. Among the numerous risks to which these workers are exposed, one of them deserves to be highlighted: the psychosocial, considered harmful to mental and physical health and generated by psychological and social mechanisms. Workers who develop their activities in direct contact with people constitute the most exposed group ${ }^{(6)}$, as is the case of nursing.

Work, as a generator of mental illness, has fostered a considerable source of debate and discussion. In most developed countries, mental disorders have already replaced musculoskeletal disorders. Work-related health impairment is due to psychiatric problems, which include depression, anxiety, and other stress-related conditions ${ }^{(7)}$.

Most symptoms of anxiety and depression represent a specific threat to participation in work, reducing functionality and negatively affecting income, self-esteem and quality of life ${ }^{(1)}$.

In Brazil, mental illness is the third cause of disability benefit grant due to occupational incapacity ${ }^{(8)}$. Analogous data are found on the international scenario. In Norway, Minor Psychiatric Disorders (MPD) account for about $20 \%$ of medical leave episodes and about one-third of all disability pensions ${ }^{(1)}$.

MPDs refer to depressive and anxiety disorders ${ }^{(9)}$, which have been considered social and economic problems among working populations due to their high prevalence and impact on work functioning ${ }^{(10)}$. According to estimates by the World Health Organization (WHO), Brazilians have the highest anxiety rate in the world $(9.3 \%)$, and the country ranks $5^{\text {th }}$ in cases of depression $(5.8 \%)^{(9)}$.

A study that evaluated the factors associated with work absence by occupational mental disorders in the state of São Paulo showed as main causes depressive episodes (40.4\%) and anxious disorders $(19.8 \%)^{(8)}$.

Regarding MPDs, national studies with nursing workers from Rio Grande do Sul, Rio de Janeiro and Bahia found a prevalence of $20.6 \%, 27.7 \%$ and $35 \%$, respectively ${ }^{(11-13)}$.
Thus, it is considered that the knowledge of workers mental health situation, based on updated data, is an indispensable factor for the elaboration of measures with intervention in practice, which is why this study was idealized.

\section{OBJECTIVE}

To investigate the prevalence of Minor Psychiatric Disorders and associated factors in nursing workers.

\section{METHOD}

\section{Ethical aspects}

This research was approved by the Ethics Committee in Research with Human Beings, following all the recommendations of Resolution $n^{\circ} 466 / 2012$ of the Brazilian National Health Council (CNS).

\section{Design, place of study and period}

Sectional, descriptive-analytical study. Data were collected between November 2016 and January 2017, among nursing workers of a public university hospital in Paraná. The institution has 300 beds and is a reference center for the Unified Health System (SUS), serving more than 350 municipalities.

\section{Population or sample; inclusion and exclusion criteria}

At the time of the collection of information for this investigation, the institution had 680 nursing employees. For the calculation of the sample size, a prevalence of the $44 \%$ outcome, estimated by a pilot study performed in the hospital, with a 95\% confidence interval and a sampling error of $5 \%$ was considered. Correction was performed for the finite population and stratified by professional category, obtaining a sample of 243 workers. Considering possible losses, $20 \%$ was added to the size of this sample.

The following inclusion criteria were established: nurses who have worked for at least 12 months. Those who were on leave of absence or away of professional activities for any reason during the collection period and were re-qualified in another function were excluded, in addition to those who had returned to work in a period shorter than 30 days, according to criteria determined by the Self-Reporting Questionnaire (SRQ-20 ) used in this research ${ }^{(14)}$.

\section{Study protocol}

To collect data, a structured and self-administered questionnaire was used, containing sociodemographic, occupational, psychosocial aspects of work and mental health. Workers were approached by one of the authors of this study, in the working place and in working hours; after clarifying the research objectives, the questionnaires were delivered and collected by the researcher.

The dependent variable MPD was measured by SRQ-20, developed by $\mathrm{WHO}$ and validated for the Brazilian population ${ }^{(14)}$. 
The instrument has 20 dichotomous questions (yes/no) to track non-psychotic disorders, which evaluate depressive, somatic and anxiety symptoms.

The cut-off point used for suspected MPD was seven or more positive responses, based on previous research with health work$\mathrm{ers}^{(15)}$. The questions were grouped by symptoms and classified into the following categories: depressive-anxious mood, somatic symptoms, decreased vital energy and depressive thoughts ${ }^{(16)}$.

The exposure variable related to psychosocial aspects was evaluated by two models, Demand-Control-Support (DCS) and Effort-Reward Imbalance (ERI). The Swedish Demand-ControlSupport Questionnaire (DCSQ), validated for the Brazilian population, was used ${ }^{(17)}$. The DCSQ consists of 17 questions, five to assess psychological demand, six to assess control, and six to investigate social support. For the categorization of the dimension (high/low), the median was adopted as the cut-off point after verification of asymmetric data distribution. Subsequently, from the association of dimensions, the work experience was classified as: active work (high demand and high control); passive work (low demand and low control); low stress (low demand and high control) and high stress (high demand and low control). The social support dimension was evaluated separately because high social support was used as a reference category ${ }^{(17)}$.

The Brazilian version of the Effort-Reward Imbalance (ERI) scale $^{(18)}$ is composed of 23 questions. Six of them evaluate the effort, 11, the reward, and six, the over-commitment. The three dimensions were dichotomized (high/low), and the cut-off point is the median. In order to analyze the relations between effort and reward, the score of each dimension was initially calculated, and then a ratio was constructed using the formula: $\mathrm{e} \div(\mathrm{r} \times$ c), where " $\mathrm{e}$ " is the score obtained by the effort questions; " $r$ " is the score obtained by summing the reward questions, and " $\mathrm{C}$ " is a correction factor $(0.545454)$, considering the number of items in the numerator compared to the denominator $(6 / 11)$. Values close to zero indicate a favorable condition, that is, low effort and high reward, and higher values indicate greater effort and lower reward ${ }^{(19)}$. The dimension of over-commitment was separately analyzed, and the absence of over-commitment was used as reference category ${ }^{(18)}$.

\section{Analysis of results and statistics}

Data were analyzed and processed using the Statistical Package for Social Sciences (SPSS), version 20.0, after double typing. For the sociodemographic and occupational variables, absolute and relative frequencies were calculated when qualitative, and measures of central tendency, dispersion, minimum and maximum when quantitative.

The bivariate analyses were performed to verify the associations between the MPD (dependent variable) and the other variables; the statistical significance was assessed using the Chi-squared test or the Fisher's exact test $(p<0.05)$. For the multivariate analysis of binary logistic regression (Stepwise method), the variables showing $p<0.20$ were presented. The Odds Ratio (OR) and their respective Confidence Intervals $(95 \% \mathrm{Cl})$ were estimated considering a significant association with the outcome of variables that presented $p<0.05$.

\section{RESULTS}

The study group consisted of 285 nursing workers and the losses, based on the sample calculation, were $2.1 \%(n=6)$, resulting from incorrectly filling out of the questionnaire. The overall prevalence of suspected MPD among nursing workers was $32.6 \%(n=93)$ in the sample investigated.

The mean of the SRQ-20 affirmative responses was 4.90 $( \pm 4.5)$, with a minimum of zero and a maximum of 19 . The highest frequency of positive responses was identified in the somatic symptoms group $(66.6 \%)$, followed by symptoms of depressive/anxious mood $(62.5 \%)$, decreased energy $(60.8 \%)$ and depressive thinking (23.2\%).

The questions that presented the highest prevalence of positive responses were: "Do you feel nervous, tense, or worried?", with $50.5 \%(n=144)$, followed by "Do you have frequent headaches?", with $41.8 \%(n=119)$, "Do you sleep poorly?", with $41.1 \%(n=117)$, "Do you feel tired all the time?", with $36.1 \%$ $(n=103)$, and "Do you have unpleasant sensations in your stomach?", with $35.1 \%(n=100)$.

Table 1 shows the data referring to the prevalence of MPD and the association with the sociodemographic and occupational characteristics of nursing workers. Gender, income and work shift were significantly associated with MPD $(p<0.05)$.

Table 1 - Sociodemographic and occupational characteristics and the association with Minor Psychiatric Disorders in nursing workers ( $N=285)$, Paraná, Brazil, 2016-2017

\begin{tabular}{|c|c|c|c|}
\hline $\begin{array}{l}\text { Sociodemographic } \\
\text { characteristics }\end{array}$ & $\begin{array}{l}\text { Total } \\
\text { n (\%) }\end{array}$ & $\begin{array}{l}\mathrm{MDP}^{+} \\
\mathrm{n}(\%)\end{array}$ & $p$ value* \\
\hline Gender & & & $<0.001$ \\
\hline Female & $214(75.1)$ & 85 (91.4) & \\
\hline Male & $71(24.9)$ & $8(8.6)$ & \\
\hline Age group (years) & & & 0.144 \\
\hline $23-31$ & $16(5.6)$ & $4(4.3)$ & \\
\hline $32-40$ & $62(21.8)$ & $27(29.0)$ & \\
\hline $41-49$ & $113(39.6)$ & $39(42.0)$ & \\
\hline $50-58$ & $79(27.7)$ & $19(20.4)$ & \\
\hline$>59$ & $15(5.3)$ & $4(4.3)$ & \\
\hline Marital status & & & 0.158 \\
\hline Single & $41(14.4)$ & $11(11.8)$ & \\
\hline Married/Common-law married & $191(67.0)$ & $59(63.5)$ & \\
\hline Divorced/Separated/Widowed & $53(18.6)$ & $23(24.7)$ & \\
\hline Children & & & 0.249 \\
\hline Without & $54(18.9)$ & $15(16.1)$ & \\
\hline With & $231(81.1)$ & 78 (83.9) & \\
\hline Formal Education & & & 0.121 \\
\hline Technician & $52(18.2)$ & $19(20.5)$ & \\
\hline Higher Education & $117(41.1)$ & $34(36.5)$ & \\
\hline Specialization & $98(34.4)$ & $38(40.9)$ & \\
\hline Masters/Doctorate Degree & $18(6.3)$ & $2(2.1)$ & \\
\hline MW income** $(\mathrm{n}=182) * * *$ & & & 0.018 \\
\hline Up to 4 & $45(24.7)$ & $24(36.4)$ & \\
\hline $4-7$ & $92(50.6)$ & $30(45.4)$ & \\
\hline$>7$ & $45(24.7)$ & 12 (18.2) & \\
\hline
\end{tabular}

To be continued 
Table 1 (concluded)

\begin{tabular}{|c|c|c|c|}
\hline $\begin{array}{l}\text { Occupational } \\
\text { characteristics }\end{array}$ & $\begin{array}{l}\text { Total } \\
\text { n (\%) }\end{array}$ & $\begin{array}{c}\mathrm{MDP}^{+} \\
\mathbf{n}(\%)\end{array}$ & $p$ value* \\
\hline Professional category & & & 0.195 \\
\hline Nursing assistant & $82(28.8)$ & $28(30.1)$ & \\
\hline Nursing technician & $157(55.1)$ & $53(57.0)$ & \\
\hline Nurse & $46(16.1)$ & $12(12.9)$ & \\
\hline Work shift & & & 0.038 \\
\hline Daytime & $161(56.5)$ & $60(64.5)$ & \\
\hline Nighttime & $124(43.5)$ & 33 (35.5) & \\
\hline Work sector & & & 0.540 \\
\hline Outpatient clinic & $25(8.8)$ & $9(9.6)$ & \\
\hline Surgical ward & $54(18.9)$ & $13(14.0)$ & \\
\hline Infirmary & $110(38.6)$ & $38(42.0)$ & \\
\hline Emergencies & $51(17.9)$ & $19(20.4)$ & \\
\hline $\mathrm{ICU}$ & $45(15.8)$ & $13(14.0)$ & \\
\hline Workload (hours) & & & 0.490 \\
\hline Up to 40 & $204(71.6)$ & $66(71.0)$ & \\
\hline Over 40 & $81(28.4)$ & $27(29.0)$ & \\
\hline Time in the Institution (years) & & & 0.680 \\
\hline Up to 5 & $72(25.3)$ & $25(26.9)$ & \\
\hline 6 to 10 & $64(22.5)$ & $24(25.8)$ & \\
\hline 11 to 20 & $46(16.1)$ & $14(15.0)$ & \\
\hline Over 20 & $103(36.1)$ & $30(32.3)$ & \\
\hline Other work & & & 0.540 \\
\hline No & $217(76.1)$ & $71(76.3)$ & \\
\hline Yes & $68(23.9)$ & $22(23.7)$ & \\
\hline
\end{tabular}

Note: $+M P D=$ Minor Psychiatric Disorders; $* P$-value of the Chi-squared test; and Fisher's Exact test for children, professional category, work shift, workload and other work; **MW = Minimum Wage; in 2017 $=R \$ 937.00$; ***Participants who answered the income question.

Table 2 - Indicators of psychosocial stress at work among nursing workers ( $N=285)$, Paraná, Brazil, 2016-2017

\begin{tabular}{|c|c|c|c|}
\hline Models of psychosocial stress & $\begin{array}{l}\text { Total } \\
\text { n (\%) }\end{array}$ & $\begin{array}{c}\text { MPD }^{+} \\
\text {n (\%) }\end{array}$ & $\underset{\text { value* }}{p}$ \\
\hline \multicolumn{4}{|l|}{ Demand-control and social support } \\
\hline Low demand ( $\downarrow$ demand $/ \uparrow$ control) & $38(13.3)$ & $13(14.0)$ & $<0.001$ \\
\hline Active work ( $\uparrow$ demand/ $/ \uparrow$ control) & $49(17.2)$ & $27(29.0)$ & \\
\hline Passive work ( $\downarrow$ demand $\left./ \downarrow_{\text {control }}\right)$ & $125(43.9)$ & $21(22.6)$ & \\
\hline High demand ( $\uparrow$ demand $/ \downarrow_{\text {control) }}$ & $73(25.6)$ & $32(34.4)$ & \\
\hline \multicolumn{4}{|l|}{ Social support } \\
\hline Low & $161(56.5)$ & $65(69.9)$ & 0.001 \\
\hline High & $124(43.5)$ & $28(30.1)$ & \\
\hline \multicolumn{4}{|l|}{ Effort-reward imbalance } \\
\hline $\mathrm{ERI}^{* *} \leq 1$ & $58(20.4)$ & $25(26.9)$ & 0.042 \\
\hline ERI $>1$ & $227(79.6)$ & $68(73.1)$ & \\
\hline \multicolumn{4}{|l|}{ Over-commitment } \\
\hline No & $166(58.2)$ & $31(33.3)$ & $<0.001$ \\
\hline Yes & $119(41.8)$ & $62(66.7)$ & \\
\hline
\end{tabular}

Note: ${ }^{\dagger} M P D=$ Minor Psychic Disorders; ${ }^{*} p$-value of the Chi-squared test; and Fisher's exact test for effort-reward imbalance; $* * E R I=$ Effort-Reward Imbalance.

Regarding the psychosocial aspects of work, most workers were classified as follows: passive work (43.9\%); high-demand work $(25.6 \%)$; active work (17.2\%) and low-demand work
(13.3\%). Low social support (56.5\%) was reported. In the ERI relationship, there was a high effort-reward imbalance $(79.6 \%)$ and absence of over-commitment (58.2\%).

Considering MPD, the prevalence of high-demand work $(34.4 \%)$ was the highest; low social support (69.9\%); high effort-reward imbalance $(73.1 \%)$ and over-commitment work $(66.7 \%)$. All variables related to psychosocial aspects were significantly associated with the outcome $(p<0.05)$ (Table 2$)$.

After the bivariate, the analysis of the multivariate model continued. In this analysis, with possible variables associated with the outcome, the following remained as significant predictors associated with MPD: female gender, which increased in six times the chances of developing the outcome; married/common-law married status and high-demand work, with approximately three times greater probabilities; high effortreward imbalance, with two times greater chance when compared to the non-exposed group; and presence of over-commitment, increasing almost five times the probability of developing MPD (Table 3).

Table 3 - Factors associated with Minor Psychiatric Disorders in nursing workers ( $N=285)$, Paraná, Brazil, 2016-2017

\begin{tabular}{|c|c|c|}
\hline Characteristics & OR $(95 \% \mathrm{Cl})$ & $p$ value \\
\hline \multicolumn{3}{|l|}{ Gender } \\
\hline Male & 1.00 & \\
\hline Female & $6.19(2.23-17.19)$ & $<0.001$ \\
\hline \multicolumn{3}{|l|}{ Marital status } \\
\hline Single & 1.00 & \\
\hline Married/Common-law married & $3.43(1.23-9.52)$ & 0.018 \\
\hline Divorced/Separated/Widowed & $1.10(0.55-2.17)$ & 0.784 \\
\hline \multicolumn{3}{|l|}{ Demand-control } \\
\hline Low-demand work & 1.00 & \\
\hline Active work & $0.53(0.24-1.17)$ & 0.119 \\
\hline Passive work & $1.74(0.79-3.83)$ & 0.166 \\
\hline High-demand work & $3.04(1.34-6.87)$ & 0.007 \\
\hline \multicolumn{3}{|l|}{ Effort-reward imbalance } \\
\hline $\mathrm{ERI}^{*} \leq 1$ & 1.00 & \\
\hline $\mathrm{ERI}>1$ & $2.27(1.13-5.60)$ & 0.047 \\
\hline \multicolumn{3}{|l|}{ Over-commitment } \\
\hline No & 1.00 & \\
\hline Yes & $4.97(2.25-10.98)$ & $<0.001$ \\
\hline
\end{tabular}

Note: ${ }^{*} E R I=$ Effort-Reward Imbalance.

\section{DISCUSSION}

The prevalence of MPD found in this study (32.6\%) was higher than that observed in other investigations with health workers, with prevalence between $17.1 \%$ and $27.9 \%{ }^{(15,20-21)}$. However, similar numbers were reported in studies with nursing workers from hospitals in Bahia (35.0\%) and Rio Grande do Sul $(33.7 \%)^{(4,13)}$.

A possible explanation for the greater occurrence of MPD in nursing focuses on the unsatisfactory conditions of the work process, such as the complexity of hospital area, high patient demand, intense work rhythm, weekend shifts, working in shifts, conflicts in personal relationships, poor human and material resources, and low recognition and appreciation ${ }^{(13,21-22)}$. 
Note that MPDs may reflect negatively on other aspects of personal and professional life, since some studies have shown their negative relation with satisfaction ${ }^{(20)}$, reduced capacity for work ${ }^{(4)}$ and Burnout $^{(12)}$. In the Dutch research, the reduction in work productivity was reported in three out of four workers with mental disorders, compared to one out of four among those without the illness ${ }^{(10)}$.

Regarding the symptom groups, the somatic patients had a higher prevalence in the sample studied, which is in line with other studies that approached nursing workers ${ }^{(4,23)}$. Among Indian nurses, there was a high perception of stress and also a low satisfaction at work related to the increase of somatic symptoms $(p<0.001)$. Exposure to emotional problems coming from contact with the patient under various conditions may lead to an increase in somatic symptoms ${ }^{(24)}$.

It is considered that, in addition, the symptoms reported by nursing workers may negatively interfere with the ability to work, because occurrences such as poor sleep, easy fatigue, headaches and feeling tense, nervous or worried can affect the concentration, predisposing the worker to commit adverse events. Literature describes that both fatigue and stress, from work, intensify the conditions for an eventual mistake ${ }^{(25)}$.

The symptom group related to depressive thoughts was shown to be relevant, even though it presents the lowest prevalence. These symptoms are related to the inability to play a useful role in life, lack of interest in things, worthlessness feelings and suicidal ideation that presented a prevalence of $3.9 \%$ in this study. The relationship between mental disorder and suicide, with a high predisposition in people diagnosed with depression, is reported in the literature. There is still a high risk of suicide among nurses ${ }^{(26)}$.

Regarding the variables studied, in this study there was a higher prevalence of MPD among female, young, married or commonlaw married participants, in the nursing assistant/technician categories and with income up to four minimum wages, which confirms other investigations carried out with nursing workers ${ }^{(4,27)}$.

It should also be considered that in this study, being the sample predominantly female, the greater occurrence of MPD among women is reliable. The predominance of females meets the characteristics of the nursing profile in Brazil (85.1\%) and in other countries, which corresponds to the historical profile of the profession ${ }^{(24,28)}$.

Regarding age group, although no significant association was found with the outcome, it is emphasized that younger workers were more likely to develop MPD. A European study, which investigated approximately 40,000 nurses, also found that the psychological disorder was more pronounced among younger people and seemed to decrease throughout life ${ }^{(29)}$. This finding may be related to the fact that these workers have less experience in the development of their daily activities and, therefore, less capacity to face what can trigger the mental suffering.

Low income seems to influence mental illness ${ }^{(21,26)}$, converging with the prevalence found in this sample. Purchase power can improve life conditions and, thus, reduce workers' stress $^{(30)}$.

In this study, the highest prevalence was found in the nursing assistant/technician categories. Research on the stressors experienced by nursing technicians evidenced their association with working conditions, relationships in the working environment and lack of work reward, such as low wages, disrespect, lack of incentive and recognition for the work done ${ }^{(31)}$.
Another important aspect is that workers that develop their activities in the nursing assistant/technician categories of this study had higher percentage of education background than that required for the professional performance, such as undergraduate and/or graduate degrees. Although greater schooling may lead to better socioeconomic conditions and opportunities for better insertion in the labor market, in this context higher qualification can generate discontent and undesirable effects on mental health, considering that these professionals work in a public institution, where they can only ascend to another professional category by going through a public service exam ${ }^{(4)}$.

Among the variables that remained associated with the outcome in the final model, in this study stands out the female gender, the married/common-law married status, the high-demand work, the high effort-reward imbalance, and the over-commitment at work. These results were also identified by other authors ${ }^{(4,15)}$.

Furthermore, investigations demonstrate that MPD have obtained greater prevalence among women ${ }^{(4,9)}$. A study with hospital health professionals revealed that women were 2.36 times more likely to have it $(p=0.028)^{(21)}$, which is lower than the data found in this study.

In the last decades there has been a significant increase of women in paid work. However, there was no corresponding increase of men's participation in domestic activities. Research that evaluated work and health based on gender, considering domestic work, pointed out that, due to work volume, women are more predisposed to mental illness ${ }^{(27)}$.

It is known that the greater the time spent in domestic activities, the greater the consequences on professional work, which can be aggravated when this workload is also high ${ }^{(27)}$. This condition may still explain the association of married or common-law married status with MPD, considering that most of the sample studied is composed of women, and those who have companions in their daily lives are subjected to overload of activities, facing double or triple working days.

The DCS model considers active and low-demand work to be the ideal, since it inhibits accumulated anxiety and favors motivation and learning attempts. On the other hand, passive and high-demand work are considered harmful, because the feeling of domination inhibits the perception of tension, increasing risk of psychological and physical stress and exposing workers to illness, with high-demand work being considered the greatest responsible for sickness and/or decrease of well-being. This model also assumes that a high social support in working environment can moderate the adverse impact of high-demand work ${ }^{(32)}$.

A study carried out with primary health care workers showed that, in the analysis of the isolated factors effect from the DCS model, those classified in the high-demand work had $41 \%$ more prevalence of MPD than the low-demand group. Regarding low social support, those workers were $5 \%$ more predisposed to mental disorder ${ }^{(15)}$. This result is in accordance with this study, in which social support, despite being associated with the outcome, did not remain as predictor factor of MPD.

The ERI model is based on the balance between the effort and the reward received at work and suggests that the most stressful work condition is the one that work reward does not correspond to the effort expended ${ }^{(19)}$. Evidence shows that elevated ERI is 
associated with an increased risk for development of $\mathrm{MPD}^{(7,27)}$, confirming the data from this investigation. In this sense, note that the reward to which ERI is referred is related to the recognition of work, to the prospects for professional growth and to safety at work, factors that surpass remuneration ${ }^{(19)}$.

Over-commitment was a significant predictor of MPD in this sample, increasing by almost five times the odds of developing the outcome. Workers with these characteristics tend to underestimate the demands, assuming excessive workloads and overvaluing their coping capacities; thus, they may be more exposed to experiencing unfavorable situations, increasing mental stress and illness ${ }^{(33)}$.

\section{Study limitations}

Although the objectives of this study were achieved, there was a limitation regarding the possibility of the healthy worker bias, since the investigation was carried out in workplace. Thus, those who were eventually on leave, sick from their work, were not part of the study sample, which may underestimate the prevalence of MPD in this population. Another limiting factor was that, in this study, the indicators of domestic work and family environment, which can be a source of stress and mental illness, were not evaluated.

Contributions to the nursing field, health or public policy.

The results obtained in this study contribute to the factors influencing mental health situation of nursing workers, considering that among the global goals set for 2030 are those of promoting mental health, well-being, and safe/decent working environments ${ }^{(34)}$, being fundamental the understanding of the current scenario.

\section{CONCLUSION}

The overall prevalence for MPD suspicion among nursing workers was $32.6 \%$. Higher prevalence was found among female, young, married/common-law married, in the nursing assistant/ technician categories, with income up to four minimum wages, classified as developing high-demand work, with low social support, high effort-reward imbalance and over-commitment. Variables that remained associated with the outcome in the final model were: female gender, married/common-law married status, high-demand work, high effort-reward imbalance, and over-commitment.

These data show the need for special attention to this group of workers, and also a need for the elaboration and implementation of intervention measures, aiming at organizational improvements of work and prevention of mental disorders.

\section{FUNDING}

Financial support for conducting this research offered by the Coordination for the Improvement of Higher Education Personnel (CAPES).

\section{REFERENCES}

1. Lovvik C, Shaw W, Overland S, Reme SE. Expectations and illness perceptions as predictors of benefit recipiency among workers with common mental disorders: secondary analysis from a randomised controlled trial. BMJ Open[Internet]. 2014[cited 2017 Aug 15];4:e004321. Available from: https://doi.org/10.1136/bmjopen-2013-004321

2. Knuth BS, da Silva RA, Oses JP, Radtke VA, Cocco RA, Jansen K. Mental disorders among health workers in Brazil. Ciênc Saúde Colet[Internet]. 2015[cited 2017 Aug 10];20(8):2481-8. Available from: http://dx.doi.org/10.1590/1413-81232015208.05062014

3. Bronkhorst B, Tummers L, Steijn B, Vijverberg D. Organizational climate and employee mental health outcomes. Health Care Manage Rev[Internet]. 2015[cited 2017 Oct 15];40(3):254-71. Available from: https://doi.org/10.1097/HMR.0000000000000026

4. Magnago TSBS, Prochnow A, Urbanetto JS, Greco PBT, Beltrame M, Luz EMF. Relationship between work ability in nursing and minor psychological disorders. Texto Contexto Enferm[Internet]. 2015[cited 2017 Dec 15];24(2):362-70. Available from: http:// dx.doi.org/10.1590/0104-07072015002580013

5. Jaracz M, Rosiak I, Bertrand-Bucińska A, Jaskulski M, Nieżurawska J, Borkowska A. Affective temperament, job stress and professional burnout in nurses and civil servants. PLoS One[Internet]. 2017[cited 2017 Sep 20];6;12(6):e0176698. Available from: https://doi. org/10.1371/journal.pone.0176698

6. Giurgiu DI, Jeoffrion C, Roland-Lévy C, Grasset B, Dessomme BK, Moret L, et al. Wellbeing and occupational risk perception among health care workers: a multicenter study in Morocco and France. J Occup Med Toxicol[Internet]. 2016[cited 2017 Oct 20];11(20). Available from: https://doi.org/10.1186/s12995-016-0110-0

7. Harvey SB, Modini M, Joyce S, Milligan-Saville JS, Tan L, Mykletun A, et al. Can work make you mentally ill? a systematic metareview of work-related risk factors for common mental health problems. Occup Environ Med[Internet]. 2017[cited 2017 Oct 20];74(4):301-10. Available from: https://doi.org/10.1136/oemed-2016-104015

8. Silva-Jr JS, Fischer FM. Sickness absence due to mental disorders and psychosocial stressors at work. Rev Bras Epidemiol[Internet]. 2015[cited 2017 Nov 10];18(4):735-44. Available from: http://dx.doi.org/10.1590/1980-5497201500040005

9. World Health Organization-WHO. Depression and other common mental disorders: global health estimates[Internet]. Geneva: WHO; 2017[cited 2017 Aug 30]. Available from: http://www.who.int/mental_health/management/depression/prevalence_global_health_estimates/en/

10. Ubalde-Lopez M, Arends I, Almansa J, Delclos GL, Gimeno D, Bültmann U. Beyond return to work: the effect of multimorbidity 
on work functioning trajectories after sick leave due to common mental disorders. J Occup Rehabil[Internet]. 2017 [cited 2017 Aug 15];27(2):210-7. Available from: https://doi.org/10.1007/s10926-016-9647-0

11. Urbanetto JS, Magalhaes MCC, Maciel VO, SantAnna VM, Gustavo AS, Poli-de-Figueiredo CE, et al. Work-related stress according to the demand-control model and minor psychic disorders in nursing workers. Rev Esc Enferm USP[Internet]. 2013 [cited 2017 Aug 15];47(5):1180-6. Available from: http://dx.doi.org/10.1590/S0080-623420130000500024

12. Silva JLL, Soares RS, Costa FS, Ramos DS, Lima FB, Teixeira LR. Psychosocial factors and prevalence of burnout syndrome among nursing workers in intensive care units. Rev Bras Ter Intensiva[Internet]. 2015[cited 2017 Sep 17];27(2):125-33. Available from: http://dx.doi.org/10.5935/0103-507X.20150023

13. Rodrigues EP, Rodrigues US, Oliveira LMM, Laudano RCS, Nascimento Sobrinho CL. Prevalência de transtornos mentais comuns em trabalhadores de enfermagem em um hospital da Bahia. Rev Bras Enferm[Internet]. 2014[cited 2017 Aug 12];67(2):296-301. Available from: http://dx.doi.org/10.5935/0034-7167.20140040

14. Mari JJ, Williams P. A validity study of a psychiatric screening questionnaire (SRQ-20) in primary care in of São Paulo. Br J Psychiatry. 1986;148:23-6.

15. Mattos AIS, Araújo TM, Almeida MMG. Interaction between demand-control and social support in the occurrence of common mental disorders. Rev Saúde Pública[Internet]. 2017[cited 2017 Sep 15];51:48. Available from: https://doi.org/10.1590/ s1518-8787.2017051006446

16. Santos KOB, Araújo TM, Oliveira NF. Estrutura fatorial e consistência interna do Self-Reporting Questionnaire (SRQ-20) em população urbana. Cad Saúde Pública[Internet]. 2009[cited 2017 Sep 15];25(1):214-22. Available from: http://dx.doi.org/10.1590/ S0102-311X2009000100023

17. Alves MGM, Chor D, Faerstein E, Lopes CS, Werneck GL. Short version of the "job stress scale": a Portuguese-language adaptation. Rev Saúde Pública[Internet]. 2004[cited 2017 Oct 15];38(2):164-71. Available from: http://www.scielo.br/pdf/rsp/v38n2/en_19774.pdf

18. Silva L, Barreto SM. Adaptação transcultural para o português brasileiro da escala effort-reward imbalance: um estudo com trabalhadores de banco. Rev Panam Salud Pública[Internet]. 2010[cited 2017 Nov 10];27(1):32-6. Available from: http://dx.doi. org/10.1590/S1020-49892010000100005

19. Siegrist J, Starke D, Chandola T, Godin I, Marmot M, Niedhammer I, et al. The measurement of effort-reward imbalance at work: European comparisons. Soc Sci Med[Internet]. 2004[cited 2017 Nov 10];58(8):1483-99. Available from: https://doi.org/10.1016/ S0277-9536(03)00351-4

20. Pai DD, Lautert L, Souza SBC, Marziale MHP, Tavares JP. Violence, burnout and minor psychiatric disorders in hospital work. Rev EsC Enferm USP[Internet]. 2015[cited 2017 Sep 20];49(3):457-64. Available from: http://dx.doi.org/10.1590/S0080-623420150000300014

21. Alves AP, Pedrosa LAK, Coimbra MAR, Miranzi MAS, Hass VJ. Prevalência de transtornos mentais comuns entre profissionais de saúde. Rev Enferm UERJ[Internet]. 2015[cited 2017 Oct 12];23(1):64-9. Available from: http://www.epublicacoes.uerj.br/index. php/enfermagemuerj/article/view/8150

22. Santana LL, Sarquis LMM, Brey C, Miranda FMA, Felli VEA. Absenteeism due to mental disorders in health professionals at a hospital in southern Brazil. Rev Gaúcha Enferm[Internet]. 2016[cited 2017 Aug 15];37(1):e53485. Available from: http://dx.doi. org/10.1590/1983-1447.2016.01.53485

23. Tito RS, Baptista PCP, Silva FJ, Felli VEA. Mental health problems among nurses in paediatric cardiac intensive care. Br J Nurs[Internet]. 2017[cited 2017 Oct 15];26(15):870-3. Available from: https://doi.org/10.12968/bjon.2017.26.15.870

24. Gandhi S, Sangeetha G, Ahmed N, Chaturvedi SK. Somatic symptoms, perceived stress and perceived job satisfaction among nurses working in an Indian psychiatric hospital. Asian J Psychiatr[Internet]. 2014 Dec[cited 2017 Oct 12];12(1):77-81. Available from: https://doi.org/10.1016/j.ajp.2014.06.015

25. Forte ECN, Machado FL, Pires DEP. Nursing's relationship with medication errors: an integrative review. Cogitare Enferm[Internet]. 2016[cited 2017 Dec 15];21(Esp):01-10. Available from: http://dx.doi.org/10.5380/ce.v21i5.43324

26. Silva DSD, Tavares NVS, Alexandre ARG, Freitas DA, Brêda MZ, Albuquerque MCS, et al. Depression and suicide risk among nursing professionals: an integrative review. Rev Esc Enferm USP[Internet]. 2015[cited 2017 Sep 17];49(6):1023-31. Available from: http://dx.doi.org/10.1590/S0080-623420150000600020

27. Rotenberg L, Silva-Costa A, Griep RH. Mental health and poor recovery in female nursing workers: a contribution to the study of gender inequities. Rev Panam Salud Publica[Internet]. 2014 [cited 2017 Oct 10];35(3):179-85. Available from: https://doi. org/10.1177/1049732314557087

28. Machado MH, Aguiar Filho W, Lacerda WF, Oliveira E, Lemos W, Wermelinger M, et al. Características gerais da enfermagem: o perfil sócio demográfico. Enferm Foco[Internet]. 2016[cited 2017 Nov 10];7:09-14. Available from: http://revista.portalcofen.gov. br/index.php/enfermagem/article/view/686/296

29. Van der Heijden BI, Mulder RH, König C, Anselmann V. Toward a mediation model for nurses' well-being and psychological distress effects of quality of leadership and social support at work. Med [Internet] 2017[cited 2017 Sep 10];96(15):e6505. Available from: https://doi.org/10.1097/MD.0000000000006505

30. Tavares JP, Magnago TSBS, Beck CLC, Silva RM, Prestes FC, Lautert L. Prevalence of minor psychiatric disorders in nursing professors. EsC Anna Nery Rev Enferm[Internet]. 2014[cited 2017 Sep 15];18(3):407-14. Available from: http://dx.doi.org/10.5935/1414-8145.20140058 
31. Pereira SS, Teixeira CAB, Reisdorfer E, Vieira MV, Gherardi-Donato ECS, Cardoso L. The relationship between occupational stressors and coping strategies in nursing technicians. Texto Contexto Enferm[Internet]. 2016[cited 2017 Oct 15];25(4):e2920014. Available from: http://dx.doi.org/10.1590/0104-07072016002920014

32. Theorell T, Karasek RA. Current issues relating to psychosocial job strain and cardiovascular disease research. J Occup Health Psychol[Internet]. 1996[cited 2017 Aug 20];1(1):9-26. Available from: https://doi.org/10.1037/1076-8998.1.1.9

33. Martinez MC, Latorre MRDO, Fischer FM. Stressors influence work ability in different age groups of nursing professionals: 2-year follow-up. Ciênc Saúde Colet[Internet]. 2017[cited 2017 Aug 25];22(5):1589-600. Available from: http://dx.doi. org/10.1590/1413-81232017225.09682015

34. Organización Mundial de la Salud. Agenda de Salud Sostenible para las Américas 2018-2030: un Ilamado a la acción para la saluld y el bienestar en la Región de las Américas[Internet]. Washington: OMS; 2017[cited 2017 Aug 15]. Available from: http:// www.paho.org/hq/index.php?option $=$ com_content\&view $=$ article\&id $=13246 \% 3$ Ahealth-agenda-americas \&catid $=9277 \% 3 \mathrm{Aco}$ ntents\&ltemid $=42349 \&$ lang $=$ es 